\title{
Initial Stages of Tundra Shrub Litter Decomposition May Be Accelerated by Deeper Winter Snow But Slowed Down by Spring Warming
}

\author{
Daan Blok, ${ }^{1 *}$ Bo Elberling, ${ }^{1}$ and Anders Michelsen ${ }^{1,2}$
}

\begin{abstract}
${ }^{1}$ Department of Geosciences and Natural Resource Management, Center for Permafrost (CENPERM), University of Copenhagen, Øster Voldgade 10, Copenhagen 1350, Denmark; ${ }^{2}$ Department of Biology, University of Copenhagen, Universitetsparken 15, Copenhagen 2100, Denmark
\end{abstract}

\begin{abstract}
The Arctic climate is projected to change during the coming century, with expected higher air temperatures and increased winter snowfall. These climatic changes might alter litter decomposition rates, which in turn could affect carbon (C) and nitrogen $(\mathrm{N})$ cycling rates in tundra ecosystems. However, little is known of seasonal climate change effects on plant litter decomposition rates and $\mathrm{N}$ dynamics, hampering predictions of future arctic vegetation composition and the tundra $\mathrm{C}$ balance. We tested the effects of snow addition (snow fences), warming (open top chambers), and shrub removal (clipping), using a full-factorial experiment, on mass loss and $\mathrm{N}$ dynamics of two shrub tissue types with contrasting quality: deciduous shrub leaf litter (Salix glauca) and
\end{abstract}

Received 4 December 2014; accepted 7 August 2015; published online 7 October 2015

Electronic supplementary material: The online version of this article (doi:10.1007/s10021-015-9924-3) contains supplementary material, which is available to authorized users.

Author Contributions D.B. conceived the project, performed the experiment, and analyzed data. D.B. wrote the paper with contributions from B.E. and A.M. Nitrogen isotopes were measured by A.M.

*Corresponding author; e-mail: daanblok@gmail.com evergreen shrub shoots (Cassiope tetragona). We performed a 10.5-month decomposition experiment in a low-arctic shrub tundra heath in WestGreenland. Field incubations started in late fall, with harvests made after 249, 273, and 319 days of field incubation during early spring, summer and fall of the next year, respectively. We observed a positive effect of deeper snow on winter mass loss which is considered a result of observed higher soil winter temperatures and corresponding increased winter microbial litter decomposition in deep-snow plots. In contrast, warming reduced litter mass loss during spring, possibly because the dry spring conditions might have dried out the litter layer and thereby limited microbial litter decomposition. Shrub removal had a small positive effect on litter mass loss for $C$. tetragona during summer, but not for $S$. glauca. Nitrogen dynamics in decomposing leaves and shoots were not affected by the treatments but did show differences in temporal patterns between tissue types: there was a net immobilization of $\mathrm{N}$ by $C$. tetragona shoots after the winter incubation, while $S$. glauca leaf $\mathrm{N}$-pools were unaltered over time. Our results support the widely hypothesized positive linkage between winter snow depth and litter decomposition rates in tundra ecosystems, but our results do not reveal changes in $\mathrm{N}$ dynamics during initial decomposition stages. Our study also shows contrasting impacts of spring warming and snow 
addition on shrub decomposition rates that might have important consequences for plant community composition and vegetation-climate feedbacks in rapidly changing tundra ecosystems.
Key words: plant-climate interactions; tundra; litter decomposition; snow addition; spring warming; snow-shrub hypothesis.

\section{INTRODUCTION}

Although decomposition of plant litter plays a major role in the global carbon (C) cycle, Earth system model predictions are currently hampered by limited knowledge on the potential contrasting winter and summer climate change impacts on decomposition rates through their effects on microbial decomposer communities and plant-soil nitrogen (N) dynamics (Bonan and others 2013; Wieder and others 2013). Climatic changes in the Arctic could influence plant decomposition rates, which in turn might affect tundra $\mathrm{C}$ and $\mathrm{N}$ cycling (Hobbie 1996) and tundra ecosystem C storage (Mack and others 2004; Lupascu and others 2014). Changes in plant decomposition rates might alter the $\mathrm{N}$ availability in nutrient-poor tundra ecosystems that in turn might modify plant species composition through plantplant and plant-microbe competition for N (Sistla and others 2014). As a result, changes in plant decomposition rates might alter the tundra $\mathrm{C}$ balance by modifying the quality and quantity of soil organic matter inputs (Cornelissen and others 2007). If arctic warming would lead to higher plant decomposition rates (Aerts 2006) and associated Nrelease (Hobbie 1996), plant functional types such as deciduous shrubs with high $\mathrm{N}$ uptake capacity and high potential growth rates might increase in dominance (Elmendorf and others 2012a).

As a result of the expected rising air temperatures (IPCC 2013) and changes in winter precipitation regimes (Bintanja and Selten 2014) in the tundra biome during the coming century, tundra shrub growth is expected to proliferate, with shrubs increasing in stature and cover (Myers-Smith and others 2011; Elmendorf and others 2012b). By trapping snow with their branches during the winter-time, shrubs can locally increase the snow depth and thus raise winter soil temperatures, thereby potentially increase winter soil mineralization rates (Schimel and others 2004) and plant $\mathrm{N}$ availability (Vankoughnett and Grogan 2014). When shrubs are able to acquire higher amounts of $\mathrm{N}$ under deepsnow conditions, as recently demonstrated in HighArctic tundra (Blok and others 2015; Semenchuk and others 2015), a positive feedback can set up between shrub height growth and winter snow depth. This positive feedback has been termed the "snow-shrub hypothesis" (Sturm and others 2001). Despite observations of enhanced plant decomposition rates with deeper snow along natural snow depth gradients (Saccone and others 2013; Carbognani and others 2014) and increased winter soil respiration rates under deeper snow (Natali and others 2014), there is of yet no direct experimental evidence that deeper snow accelerates litter decomposition rates in arctic tundra ecosystems (DeMarco and others 2014).

Shrubs might alter the microclimate during summer in contrasting ways: on one hand, shrubs might reduce the surface albedo and create atmospheric heating (Chapin and others 2005; Sturm and others 2005a), but on the other hand, they might also lead to summer soil cooling by shrub shading (Blok and others 2010; Myers-Smith and Hik 2013). These shrub-induced changes in summer air and soil temperatures might, however, also indirectly affect decomposition rates through changes in soil moisture, as microbial decomposer communities are water dependent (Robinson and others 1995; Hicks Pries and others 2013). Shrub-controlled changes in winter soil temperatures might have carry-over effects on summer decomposition and soil respiration rates (DeMarco and others 2011), which might offset growing season carbon gains by increased plant productivity (Natali and others 2012, 2014) and thus create a positive feedback to tundra shrub expansion by increasing $\mathrm{N}$ availability to shrubs (Sturm and others 2005b). It is therefore important to simultaneously study winter and summer climate change impacts on tundra shrub decomposition rates to increase the understanding of tundra vegetation-climate feedbacks (Wookey and others 2009).

When shrubs grow taller they could potentially increase soil microbial activity by changing soil thermal conditions during winter and summer, but they could also produce greater amounts of litter and thereby create a positive feedback to N-release and shrub expansion (Sturm and others 2005b; Buckeridge and others 2010). An expansion of shrubs might also modify tundra decomposition rates by causing a shift in community-weighted plant functional traits (Cornelissen and Makoto 2013), for example, by increasing leaf lignin content, which might reduce decomposition rates 
(Cornelissen and others 2007) and ecosystem C and N cycling (Freschet and others 2012). However, the sensitivity of litter decomposition to warming has been shown to be inversely related to litter quality, with high-quality litter exhibiting a smaller decomposition response to temperature than lowquality litter because of microbial enzyme kinetics (Fierer and others 2005). Predictions on the net effect of climatic changes on tundra litter decomposition rates thus require knowledge on speciesspecific decomposition responses to changes in microclimate (Sundqvist and others 2011).

To summarize, changes in both winter and summer climate might feedback to shrub growth in tundra ecosystems through changes in decomposition rates and litter nitrogen release (Wookey and others 2009). However, winter and summer climate change effects on decomposition rates have not been well studied, especially in combination. Here, we studied the interactive effects of snow addition (snow fences), warming (open top chambers), and shrub removal (clipping), using a full-factorial experiment, on mass loss rates and nitrogen dynamics in two contrasting arctic plant tissue types: deciduous shrub Salix glauca leaf litter and evergreen shrub Cassiope tetragona green shoots. We assessed how treatment effects on decomposition rates differed among the winter, spring, and summer season during a 10.5-month incubation period in the field. Field incubations started in late fall, with harvests made after 249, 273, and 319 days of incubation during early spring, summer, and fall of the next year. We hypothesized (i) deeper snow will result in greater plant tissue mass loss and $\mathrm{N}$-release during winter by soil warming but reduced mass loss in spring because of longer snow cover; (ii) warming will increase decomposition rates and $\mathrm{N}$-release during spring, but decrease decomposition rates in summer because of microbial moisture limitation; (iii) shrub removal will decrease decomposition rates by lowering surface temperature through an increase in surface albedo; (iv) snow addition will have a larger relative effect on decomposition rates than warming (open top chamber) because of the long winter period; and finally, (v) we hypothesized treatments will have a greater effect on decomposition of low-quality $S$. glauca leaf litter than on highquality green $C$. tetragona shoots.

\section{Materials AND Methods}

\section{Site Description and Experimental Setup}

The study was performed at a mesic tundra site in the Blæsedalen valley $\left(69^{\circ} 16^{\prime} \mathrm{N}, 53^{\circ} 27^{\prime} \mathrm{W}\right)$ on the
South-tip of Disko Island, West-Greenland (Fig. S1). The area has a typical low-arctic climate with a mean annual (1992-2012) air temperature of $-3.0^{\circ} \mathrm{C}$, warmest monthly mean air temperature during July $\left(7.9^{\circ} \mathrm{C}\right)$, and coldest monthly mean air temperature during March $\left(-14.0^{\circ} \mathrm{C}\right)$, measured at Arctic Station, approximately $3 \mathrm{~km}$ from the research site (Hansen and others 2006). The vegetation at the experimental site (max vegetation height $c .10 \mathrm{~cm}$ ) is dominated by Betula nana, Vaccinium vitis-idaea, Empetrum nigrum, Salix glauca, Cassiope tetragona, and lichens (Table 1). Tall Salix glauca shrubs are present in close vicinity of the experimental site, but are confined to snowdrift areas at the foot of hill slopes and terrain with high topographic relief and have similar winter snow depths as in our snow manipulation plots. Soils consist of basaltic rock fragments, covered by a thin $(5-10 \mathrm{~cm})$ organic horizon with mean carbon to nitrogen ratios (C:N) of 22.5 (unpublished data A. Michelsen). The research site lies within the discontinuous permafrost zone. We cannot ascertain the exact active layer depth in our experimental plots by probing because of the large rocks in the soil, but two soil profiles showed that soils thawed to approximately $1.5 \mathrm{~m}$ during late-July 2012 .

During July 2012, we established an experiment to manipulate winter snow depth, temperature, and shrub cover (Fig. S1). Six replicate blocks, each with a 14.7-m-long and 1.5-m-tall snow fence, were established to create snowdrifts on the leeward (south) side of the fences during winter (snow addition). On each side of the fences, four plots measuring $2 \times 2 \mathrm{~m}$ were laid out. Plots were located between 3 and $8 \mathrm{~m}$ from the fence on the leeward snow-accumulation side of the fence in the area of maximum snow build-up and between 6 and $11 \mathrm{~m}$ from the fence on the windward side with ambient snow conditions. Half of the plots were covered year-round (starting 17/18 July 2012) by $35-\mathrm{cm}$-tall and 3-mm-thick polycarbonate hexagon open top chambers (OTCs) to increase air temperature, measuring $150 \mathrm{~cm}$ diameter at the base and $85 \mathrm{~cm}$ diameter at the top (warming). In half of the plots, shrubs were clipped at the surface during late-summer 2012 (shrub removal). Vascular and non-vascular plant cover, biomass data of removed shrub biomass, and shrub leaf-to-aboveground stem biomass ratios are presented in Table 1 . The three main treatments snow addition $(\mathrm{S})$, warming $(\mathrm{W})$, and shrub removal (R) were combined in a full-factorial design across 6 blocks ( $n=6$ plots per treatment combination), yielding 48 plots in total. Soil temperatures $(5-\mathrm{cm}$ depth) and surface air temperatures $(1-2 \mathrm{~cm}$ above the soil 
Table 1. Plant Cover ( $n=48$ plots), Removed Biomass (From Plots with Shrub Removal Treatment, $n=24$ plots), and Leaf:Branch Mass Ratios (From Plots with Shrub Removal Treatment, $n=24$ plots)

\begin{tabular}{lrcc}
\hline Functional group/species & Cover $(\%)$ & Biomass removed $\left(\mathrm{g}\right.$ dry weight $\left.\mathbf{~}^{-\mathbf{2}}\right)$ & Leaf/branch mass $(\mathrm{ratio})$ \\
\hline Deciduous shrub & $55.0(3.7)$ & $92.6(9.6)$ & $0.6(0.2)$ \\
Betula nana & $24.8(3.0)$ & $73.0(9.5)$ & $0.9(0.1)$ \\
Salix glauca & $4.7(0.8)$ & $8.1(1.2)$ & $0.7(0.0)$ \\
Vaccinium uliginosum & $25.5(1.7)$ & $11.6(1.6)$ & $2.2(0.1)$ \\
Evergreen shrub & $27.4(2.2)$ & $66.8(6.4)$ & $1.2(0.1)$ \\
Cassiope tetragona & $7.3(0.9)$ & $40.3(5.3)$ & \\
Empetrum nigrum & $16.3(1.9)$ & $26.4(3.3)$ & \\
Graminoid & $1.0(0.2)$ & & \\
Forb & $3.9(0.6)$ & & \\
Moss & $11.2(1.2)$ & & \\
Lichen & $25.4(1.9)$ & & \\
Litter & $19.0(1.0)$ & &
\end{tabular}

Values are means $(n=48$ plots for plant cover data; $n=24$ plots for biomass and leaflbranch ratio data) $\pm S E$ (between brackets). No differences in plant cover were measured between treatments at the start of the experiment; therefore, only overall means are shown. Cover was measured during summer 2012 (before shrub removal treatment commenced) and expressed as number of hits recorded in a $70 * 70 \mathrm{~cm}$ square frame with $100 \mathrm{grid}$ points. A hit was recorded when a pin, vertically lowered from the top of the canopy to the ground, touched a species. A single species could be recorded multiple times per grid point. Further, shrub biomass data from shrub removal plots are presented (removed during July 2012), together with associated leaf-to-branch ratios per shrub species removed.

surface) were measured continuously in all plots of three and two blocks, respectively $(n=2-3$ plots treatment combination ${ }^{-1}$ ), using TinyTag PB-5001 thermistor probes (Gemini Data Loggers, UK) and logged every hour. Soil moisture was measured continuously (integrated over 0 - to 5 -cm depth) in all plots of three blocks $(n=2-3$ plots treatment combination $^{-1}$ ) using Decagon EC-5 water content sensors (Decagon Devices, WA, USA) and logged every $10 \mathrm{~min}$. Snow depth measurements were carried out at 1-m intervals in all snow fences during late March 2013 in transects perpendicular to the fences, extending $10 \mathrm{~m}$ on each side. Winter snow depth and snowmelt timing was determined from daily photographs taken by automated cameras that captured three complete blocks.

\section{${ }^{15} \mathrm{~N}$-Labeling, Plant Collection, and Litterbag Construction}

Within $20 \mathrm{~m}$ of the experimental snowfence blocks, fourteen $1 \mathrm{~m}^{2}$ "spray plots" were established, with half of these spray plots dominated by evergreen shrub Cassiope tetragona and half of the spray plots dominated by deciduous shrub Salix glauca. Spray plots were sprayed six times with a $5 \mathrm{mM}$ solution of $98+$ at. $\%{ }^{15} \mathrm{~N}$-urea (Cambridge Isotope Laboratories, Inc., USA) during a two-week period in mid-July 2012 using a pressurized plant sprayer to create leaf and shoot material enriched in the heavy $\mathrm{N}$ isotope ${ }^{15} \mathrm{~N}$. Before spraying commenced, all $S$. glauca leaf litter deposited during previous years was removed to prevent mixing with ${ }^{15} \mathrm{~N}$-enriched litter and to assess ${ }^{15} \mathrm{~N}$ natural abundances. For determination of $C$. tetragona shoot $-{ }^{15} \mathrm{~N}$ natural abundances, green shoot tips from the shrub removal plots within the six experimental blocks were used. Each spray plot received $0.5 \mathrm{~L}$ of the ${ }^{15} \mathrm{~N}$-urea solution per spray round in the form of a fine mist, equal to a total of $0.2 \mathrm{~g}^{15} \mathrm{~N} \mathrm{~m}^{-2}$ for the six spray rounds combined. After spraying, plots were covered with a clear transparent foil for $24 \mathrm{~h}$ to achieve maximum ${ }^{15} \mathrm{~N}$ uptake by shoots and leaves, a method applied successfully before by Zeller and others (1998). Freshly senesced S. glauca leaf litter and C. tetragona green shoots were collected from the spray plots during leaf senescence in mid-September 2012. Collected litter and shoots were oven-dried for $24 \mathrm{~h}$ at $40^{\circ} \mathrm{C}$ to constant weight. After drying, green shoot tips of $C$. tetragona were separated from older shoot parts as ${ }^{15} \mathrm{~N}$-urea uptake through leaves presumably occurred mostly in the most recent green shoot increments. We used C. tetragona green shoot tips with low C:N ratios and $S$. glauca leaf litter material with high $\mathrm{C}: \mathrm{N}$ ratios. Green $C$. tetragona shoots most likely decompose faster than old growth gray C. tetragona shoot increments and as such cannot be regarded as true litter. The green C. tetragona shoot parts we used thus likely overestimated initial decomposition rates of $C$. tetragona litter. However, our aim was to determine climate change impacts on mass loss and $\mathrm{N}$ dynamics during early decomposition stages using two very contrasting plant tissue types. We did not attempt to compare evergreen versus deciduous shrub litter 
responses to warming or generalize responses across all tundra plant functional types. Samples of $\pm 0.35 \mathrm{~g}$ dry $S$. glauca leaf litter and $\pm 0.5 \mathrm{~g} \mathrm{C}$. tetragona green shoot tips were weighed to a precision of $0.1 \mathrm{mg}$. Samples were sealed into $30 \mathrm{~cm}^{2}$ mesh bags (hereafter referred to as litterbags) using non-corroding staples. The mesh material had $0.68 \mathrm{~mm}$ openings and an open surface area of $67 \%$, allowing water and micro-arthropod passage, while preventing leaf and shoot fragments from falling out of the litterbags (Bokhorst and Wardle 2013).

\section{Litterbag Incubation Experiment}

Three litterbags of each type were placed in all 48 plots of the experiment on October 9, 2012, 1 day after the first post-growing season winter snowfall event. Litterbags were laid out horizontally on the ground and pinned tight to the surface of the plots using non-corroding steel nails. Of each litterbag type, 10 samples were kept for determination of initial litter chemistry and ${ }^{15} \mathrm{~N}$-concentrations. The first set of litterbags (one litterbag per shrub tissue type per plot) was collected immediately after snowdrifts were completely melted on the leeward side of the fences on June 14, 2013 (winter incubation). The second set of litterbags was collected by the end of spring, July 8, 2013 (winter + spring incubation). The final, third set of litterbags was collected by the end of summer, August 23, 2013 (winter + spring + summer incubation).

\section{Mass Loss, Litter Chemistry, and Isotopic Composition}

Harvested litterbags were air-dried for several days immediately after sampling before shipment to the lab, where leaf and shoot mass was determined after oven drying at $40^{\circ} \mathrm{C}$ for $96 \mathrm{~h}$. Mass loss was determined as the fraction of initial mass lost after field incubation. Mass loss rates were calculated by dividing mass loss fractions by the incubation time in days to assess differences in decomposition rates across seasons. After mass loss determination, samples were ground to a fine powder. Approximately 3-4 mg ground $S$. glauca or C. tetragona material was packed into tin capsules to determine $\mathrm{N}$ isotopic ratios $\left({ }^{15} \mathrm{~N}:{ }^{14} \mathrm{~N}\right), \mathrm{N}$ concentrations $(\% \mathrm{~N})$, and $\mathrm{C}$ concentrations $(\% \mathrm{C})$ on an Isoprime isotope ratio mass spectrometer (Isoprime Ltd., Cheadle Hulme, UK) coupled to a CN elemental analyzer (Eurovector, Milan, Italy). The standard deviation of isotope measurements of the standards was $\pm 0.2 \mathrm{ppm}(\%)$ for $\delta^{15} \mathrm{~N}$. Total pools of ${ }^{15} \mathrm{~N}$ in $S$. glauca leaves and C. tetragona shoots were calculated from ${ }^{15} \mathrm{~N}$-enriched atom percentages (atom\% ${ }^{15} \mathrm{~N}_{\text {sample }}=100 * R_{\text {standard }} *\left(\left(\delta^{15} \mathrm{~N}_{\text {sample }} / 1000+1\right) /(1+\right.$ $\left.R_{\text {standard }} \quad *\left(\delta^{15} \mathrm{~N}_{\text {sample }} / 1000+1\right)\right) .{ }^{15} \mathrm{~N}$-enrichment atom $\%$ relative to $S$. glauca litter and C. tetragona shoot ${ }^{15} \mathrm{~N}_{\text {natural abundance }}$ (atom $\%{ }^{15} \mathrm{~N}_{\text {excess}}$ ) were calculated by deducting atm $\%{ }^{15} \mathrm{~N}_{\text {natural abundance values }}$ from atm $\%{ }^{15} \mathrm{~N}_{\text {sample. Total pools of }}{ }^{15} \mathrm{~N}_{\text {excess }}$ in $S$. glauca leaf litter and C. tetragona shoots incubated in plots were calculated by multiplying litter and shoot dry mass with atom $\%{ }^{15} \mathrm{~N}_{\text {excess }}$ values.

\section{Statistical Analyses}

Effects of snow addition, warming (OTC), and shrub removal on surface air temperature, soil temperature, soil moisture, litter mass loss, N-pools, ${ }^{15} \mathrm{~N}$-pools, \%C, \%N, and C:N ratios in remaining leaf litter and shoot mass were analyzed separately per incubation period (winter, spring, summer) using the PROC MIXED procedure in SAS Enterprise Guide 6.1. Analyses of treatment effects on litter parameters were performed separately per litter type (S. glauca leaves, C. tetragona shoots). Cumulative treatments effects (winter + spring, winter + spring + summer) were also analyzed for each litter parameter. We performed mixed-model analyses to assess seasonal treatment effects on all litter parameters, whereby we took into account the previous-season winter and winter + spring variances as fixed factor for analysis of treatment effects during spring and summer, respectively. Bonferroni corrections were applied by down-adjusting the significance threshold level threefold, taking into account the three repeated litterbag samplings over time. Thus, $P$-values below 0.017 were considered statistically significant. Data were natural log-transformed where needed to achieve normal distributions. Snow addition, warming (OTC), shrub removal, and their interactions, were selected in the models as fixed factors. Block was selected as random factor in the mixed models. We reduced the models step-wise by subsequently eliminating the three-way and the two-way interactions when these interactions were non-significant. Fixed effects were determined by the Restricted Maximum Likelihood (REML) method and degrees of freedom were estimated by the Kenward-Roger method. Remaining total N-pools and ${ }^{15} \mathrm{~N}$-pools in leaves and shoots were calculated as percentage of initial pre-incubation leaf and shoot $\mathrm{N}$ and ${ }^{15} \mathrm{~N}$-pools, respectively. We used paired t-tests to assess whether leaf and shoot $\mathrm{N}$ pools and ${ }^{15} \mathrm{~N}$-pools changed significantly over time compared to initial leaf and shoot $\mathrm{N}$ - and ${ }^{15} \mathrm{~N}$-pools. 


\section{Results}

No significant interaction effects among main treatments were observed for any of the measured variables. Therefore, only main treatment effects are presented here.

\section{Snow Depth, Soil and Surface Air Temperature, and Soil Moisture}

Winter snow depth reached up to approximately maximum $140 \mathrm{~cm}$ in deep-snow plots on the leeward side of the fences and reached a maximum of approximately $40 \mathrm{~cm}$ in windward-located ambient snow plots, covering the OTCs completely during a great part of the winter. A spring warming event resulted in almost snow-free conditions $(3 \pm 2 \mathrm{~cm})$ in ambient snow plots on March 26, 2013, whereas a thick snow layer remained until June 14, 2013 in snow addition plots $(86 \pm 5 \mathrm{~cm})$.

The snow addition treatment significantly increased surface air temperatures by approximately $1.7^{\circ} \mathrm{C}$ during the winter period $\left(F_{1,9}=12.6\right.$, $P<0.01)$, but not during spring and summer (Fig. 1A; Table 2). Winter soil temperatures were significantly higher in snow addition plots by $1.6^{\circ} \mathrm{C}$ compared to ambient snow plots $\left(F_{1,18}=61.6\right.$, $P<0.001)$, but $1.6^{\circ} \mathrm{C}$ lower than ambient snow plots during spring $\left(F_{1,18}=9.2, P<0.01\right.$; Fig. 1B; Table 2 ). Snow addition did not significantly affect soil temperatures during summer. Soil moisture was not significantly affected by the snow addition treatment during any period (Fig. 1C; Table 2).

The OTCs had a small significant warming effect $\left(0.6^{\circ} \mathrm{C}\right)$ on winter soil temperature compared to ambient plots $\left(F_{1,18}=7.9, P<0.05\right)$, but not on winter surface air temperature. During spring $\left(F_{1,8}=14.0, P<0.01\right)$ and summer $\left(F_{1,8}=64.4\right.$, $P<0.001)$, the OTCs significantly increased surface air temperature by, respectively, 2.2 and $2.7^{\circ} \mathrm{C}$ compared to plots without OTCs, but soil temperatures were not significantly different during spring and summer (Fig. 1A, B; Table 2). The OTCs did not significantly affect soil moisture during any season (Fig. 1C; Table 2), neither did they affect the timing of complete snowmelt.

Shrub removal did not significantly affect surface air temperature or soil temperature, nor did it affect soil moisture during any measurement period (Table 2).

\section{Litter Mass Loss and Nitrogen Pools}

Winter litter mass loss was significantly higher by $47 \%$ for $S$. glauca leaves $\left(F_{1,39}=25.8, P<0.001\right)$
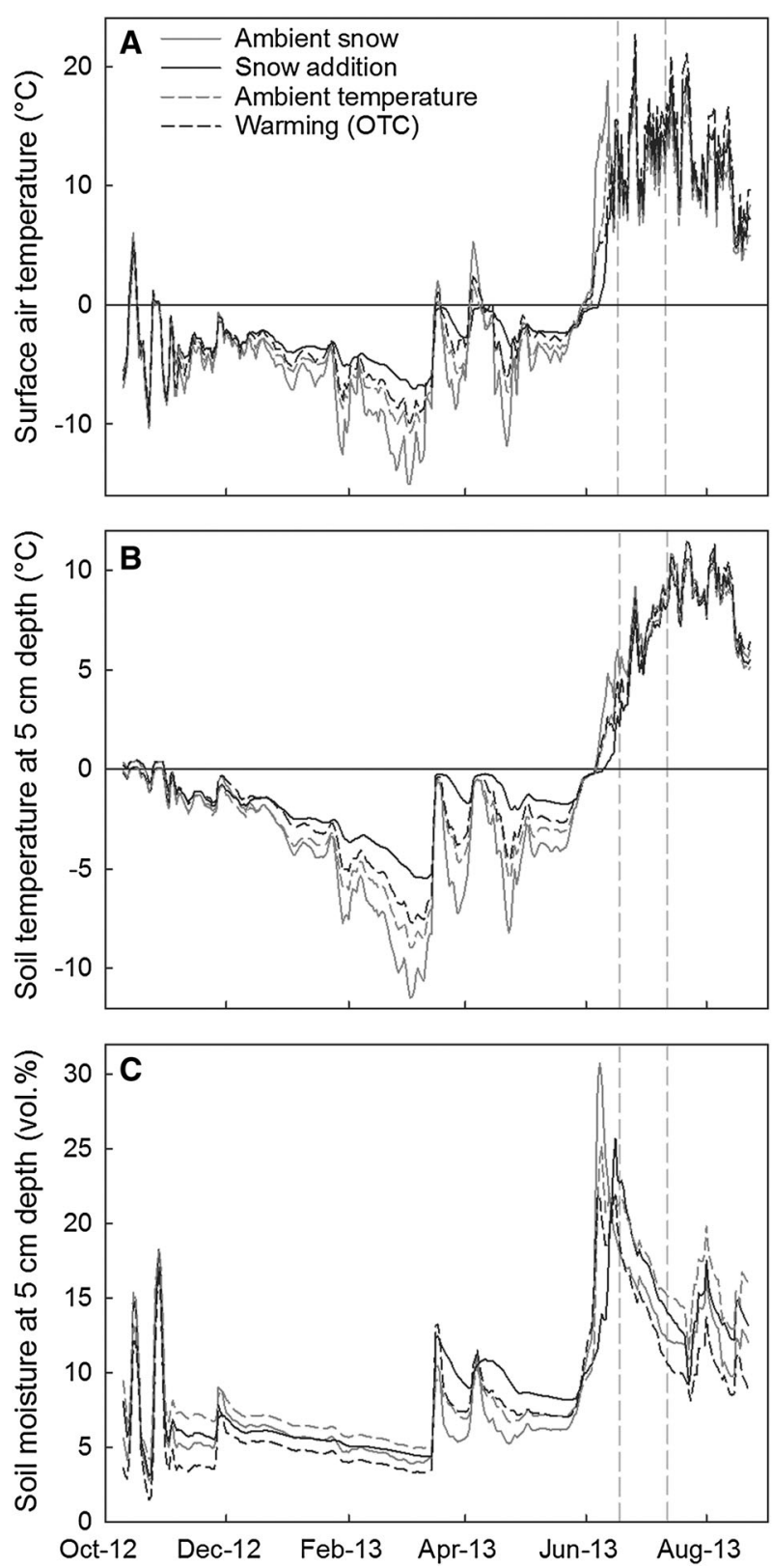

Figure 1. A Surface air temperature, B soil temperature at $5-\mathrm{cm}$ depth, and $\mathbf{C}$ soil moisture integrated over 0 - to 5 -cm depth during the decomposition experiment, presented separately for main treatments snow addition and warming (OTC), as well as their non-manipulated controls. Values are daily means $\left(n=7-12\right.$ plots treatment $\left.{ }^{-1}\right)$, with gray and black continuous lines showing values in ambient snow and snow addition plots, respectively. The gray and black dashed lines show values in ambient temperature and warmed (OTC) plots, respectively. $F$ - and $P$ values of treatment effects are presented in Table 2 . The vertical dashed gray lines indicate the start of the spring and summer period. Only snow addition and warming treatments showed persistent significant effects and are therefore presented. 
Table 2. Treatment Effects on Surface Air/Soil Temperature and Soil Moisture during the Winter, Spring, and Summer Incubation Periods

\begin{tabular}{|c|c|c|c|}
\hline & Snow addition & Warming (OTC) & Shrub removal \\
\hline \multicolumn{4}{|c|}{ Surface air temperature } \\
\hline Winter & $12.6^{* *}$ & 3.1 & 0.0 \\
\hline Spring & 0.3 & $14.0 * *$ & 3.1 \\
\hline Summer & 0.2 & $64.4^{* * *}$ & 2.8 \\
\hline \multicolumn{4}{|c|}{ Soil temperature (5-cm depth) } \\
\hline Winter & $61.6^{* * *}$ & $7.9^{*}$ & 3.6 \\
\hline Spring & $9.2 * *$ & 0.1 & 5.0 \\
\hline Summer & 2.7 & 3.4 & 1.5 \\
\hline \multicolumn{4}{|c|}{ Soil moisture $(0-5 \mathrm{~cm}$ depth $)$} \\
\hline Winter & 0.0 & 0.1 & 4.1 \\
\hline Spring & 1.0 & 0.8 & 4.2 \\
\hline Summer & 0.0 & 4.0 & 1.7 \\
\hline \multicolumn{4}{|c|}{$\begin{array}{l}\text { Measurements were made during winter ( } 10 \text { October } 2012 \text { to } 14 \text { June } 2013) \text {, spring }(15 \text { June to } 8 \text { July } 2013) \text { and summer }(9 \text { July to } 23 \text { August } 2013) \text { incubation periods. } \\
\text { Temperature was measured at the soil surface and at } 5 \text {-cm depth using soil thermistor loggers }\left(n=2-3 \text { plots treatment }{ }^{-1}\right) \text {. Soil moisture was measured over } 0 \text { - to } 5 \text {-cm depth } \\
\text { using soil moisture loggers }\left(n=2-3 \text { plots treatment }{ }^{-1}\right) \text {. Shown are F-values of main treatment effects snow addition, warming }(O T C) \text {, and shrub removal, with asterisks } \\
\left.\text { indicating the significance level }{ }^{*} P<0.05 ; * * P<0.01 ; * * * P<0.001\right) \text {. No interaction effects between main treatments were observed for any of the measured variables; } \\
\text { therefore, only main treatments were included as explanatory variables in the statistical mixed models. }\end{array}$} \\
\hline
\end{tabular}

and higher by $33 \%$ for $C$. tetragona shoots $\left(F_{1,39}=9.8, \quad P<0.01\right)$ in snow addition plots compared to litter mass loss measured in ambient snow plots (Fig. 2A; Table 3). The positive effect of deeper snow on mass loss remained significant throughout spring and summer for both $S$. glauca leaves and $C$. tetragona shoots when looking at cumulative mass losses (Fig. 2A), but not when analyzed separately for the spring and summer incubation periods and winter and winter + spring litter mass loss variances were taken into account (Table 3). A major proportion of the cumulative mass loss during the approximately 11-month incubation period took place during winter, with $87 \%$ of total C. tetragona mass loss and $72 \%$ of total $S$. glauca mass loss occurring during the snow-covered period (Fig. 2A). Total N-pools and ${ }^{15} \mathrm{~N}$-pools were not significantly affected by the snow addition treatment in either $S$. glauca leaves or $C$. tetragona shoots (Fig. 2B, C). Total N-pools of C. tetragona shoots did change significantly over time, with net $\mathrm{N}$-immobilization occurring after winter $[\mathrm{t}(47)=$ -4.41, $P<0.001]$ and winter + spring incubation [t(47) $=-3.95, P<0.001]$, followed by net $\mathrm{N}$-release to pre-incubation values after winter + spring + summer incubation $[\mathrm{t}(47)=0.73$, $P>0.01$, Fig. 2B]. No changes in S. glauca total Npools were observed over time during the incubation experiment (Fig. 2B). Urea- ${ }^{15} \mathrm{~N}$ spraying led to heavily enriched pre-incubation litter $\delta^{15} \mathrm{~N}$-values, on average $2174 \pm 134 \%$ for $C$. tetragona shoots and $6057 \pm 368 \%$ for $S$. glauca leaf litter. Temporal patterns in ${ }^{15} \mathrm{~N}$-pools differed between species, with
S. glauca leaves showing a significant loss during the winter incubation period $[\mathrm{t}(47)=-3.70$, $P<0.001]$, whereas for $C$. tetragona shoots a ${ }^{15} \mathrm{~N}$ pool loss was only apparent after the entire 11-month incubation period $[\mathrm{t}(47)=-4.09$, $P<0.001$, Fig. 2C].

Warming (OTC) had a significant negative effect on $S$. glauca leaf $\left(F_{1,38}=7.1, P<0.05\right)$ and $C$. tetragona shoot $\left(F_{1,43}=7.6, P<0.01\right)$ mass loss during spring, but did not significantly affect mass loss during summer (Table 3). The strongest significant warming effect was observed on cumulative $S$. glauca mass losses over the full wintersummer incubation period $\left(F_{1,44}=8.3, P<0.01\right)$, showing $15 \%$ lower mass loss in warmed plots by late August compared to ambient temperature plots (Fig. 2D). For C. tetragona shoots, cumulative mass losses were not significantly reduced in plots with OTCs compared to ambient temperature plots (Fig. 2D). Warming (OTC) did not significantly affect total $\mathrm{N}$ - (Fig. 2E) or ${ }^{15} \mathrm{~N}$-pools (Fig. 2F) during any incubation period (Table 3 ).

Shrub removal had a small positive effect on $C$. tetragona mass loss during the summer incubation period, but not on $S$. glauca leaf litter decomposition (Table 3). No significant effects of shrub removal on S. glauca leaf or C. tetragona shoot N-pools were observed (Fig. S2C, D, Table 3), neither were ${ }^{15} \mathrm{~N}$ pools not significantly affected by the shrub removal treatment for either $S$. glauca leaves or C. tetragona shoots during any incubation period (Table 3 ).

Mean mass loss rates were relatively constant throughout the entire incubation period, but de- 

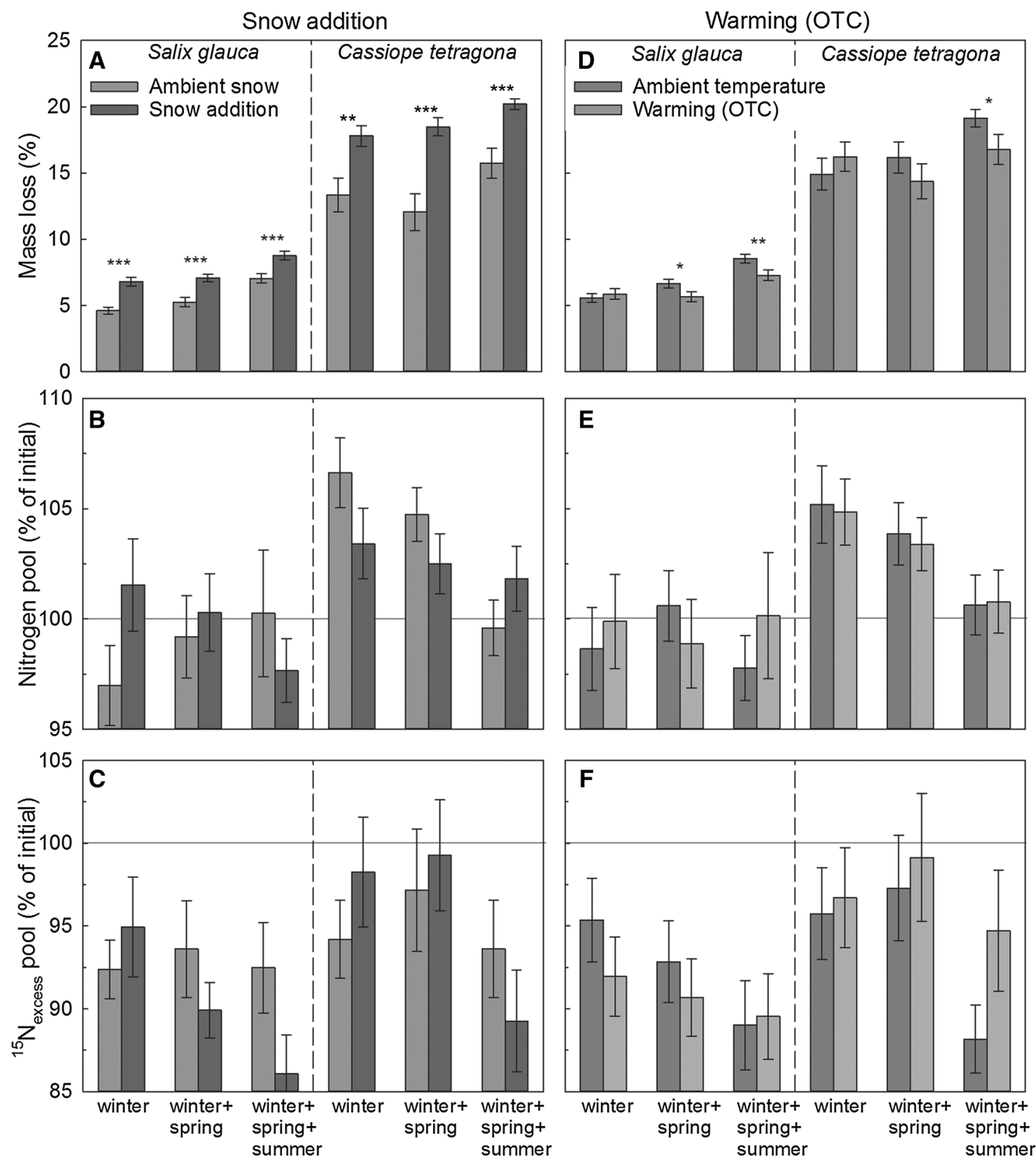

Figure 2. Mass loss $(\mathbf{A}, \mathbf{D})$, percentage total remaining nitrogen $(\mathrm{N})$ pool $(\mathbf{B}, \mathbf{E})$, and percentage total remaining ${ }^{15} \mathrm{~N}$ pool (C, F) of Salix glauca leaf litter and Cassiope tetragona shoots in plots with snow addition (left column) and warming (OTC) (right column) after incubation during winter, winter-spring, and winter-spring-summer. Values are means $(n=24$ litterbags treatment ${ }^{-1}$ incubation period ${ }^{-1}$ ). Symbols above bars indicate significance levels of treatment: ${ }^{*} P<0.05$, $* * P<0.01, * * * P<0.001$. F-values and statistics on all main treatment effects are presented in Table 3 . Only snow addition and warming showed significant treatment effects and are therefore presented. Full data of mass loss, total $\mathrm{N}$-pools, ${ }^{15} \mathrm{~N}$-pools, $\% \mathrm{C}, \% \mathrm{~N}$, and C:N ratios per treatment combination and statistical results on all main treatment effects are presented in Figure S2 and Table S3. Note the vertical axis is stunted for panel B, C, E, and F. Gray horizontal lines represent initial pre-incubation $\mathrm{N}$-pool and ${ }^{15} \mathrm{~N}$-pool values $\left(n=10\right.$ litterbags litter type $\left.{ }^{-1}\right)$.

clined in snow addition plots after the winter incubation period for C. tetragona shoots, but not for $S$. glauca leaves. Cassiope tetragona shoot mass loss rates showed a similar decline in warmed plots (OTC) after the winter incubation period, but not for S. glauca leaves (Fig. 3). 
Table 3. Treatment Effects on Leaf/Shoot Mass Loss, Nitrogen Pools, and ${ }^{15} \mathrm{~N}$-nitrogen Pools during the Winter, Spring, and Summer Incubation Periods

\begin{tabular}{|c|c|c|c|}
\hline & Mass loss (\%) & N-pool (\%initial) & ${ }^{15} \mathrm{~N}-$ pool (\%initial) \\
\hline \multicolumn{4}{|c|}{ Winter incubation period } \\
\hline \multicolumn{4}{|c|}{ Salix glauca } \\
\hline Snow addition & $25.8^{* * *}$ & 2.7 & 0.5 \\
\hline Warming (OTC) & 0.2 & 0.2 & 0.9 \\
\hline Shrub removal & 2.6 & 0.1 & 0.1 \\
\hline \multicolumn{4}{|l|}{ Cassiope tetragona } \\
\hline Snow addition & $9.8 * *$ & 2.0 & 1.0 \\
\hline Warming (OTC) & 0.5 & 0.0 & 0.1 \\
\hline Shrub removal & 0.0 & 1.6 & 2.3 \\
\hline \multicolumn{4}{|c|}{ Spring incubation period } \\
\hline \multicolumn{4}{|l|}{ Salix glauca } \\
\hline Snow addition & $7.6 * *$ & 0.0 & 1.4 \\
\hline Warming (OTC) & $7.1^{*}$ & 0.5 & 0.4 \\
\hline Shrub removal & 0.9 & 0.7 & $4.9^{*}$ \\
\hline \multicolumn{4}{|l|}{ Cassiope tetragona } \\
\hline Snow addition & $6.0 *$ & 1.9 & 0.2 \\
\hline Warming (OTC) & $7.6^{* *}$ & 0.1 & 0.1 \\
\hline Shrub removal & 0.0 & 0.1 & 0.9 \\
\hline \multirow{2}{*}{\multicolumn{4}{|c|}{$\begin{array}{l}\text { Summer incubation period } \\
\text { Salix glauca }\end{array}$}} \\
\hline & & & \\
\hline Snow addition & 4.0 & 0.8 & 2.3 \\
\hline Warming (OTC) & 4.0 & 0.7 & 0.1 \\
\hline Shrub removal & 0.0 & 1.9 & 1.1 \\
\hline \multicolumn{4}{|l|}{ Cassiope tetragona } \\
\hline Snow addition & 1.3 & 1.3 & 0.9 \\
\hline Warming (OTC) & 3.5 & 0.0 & 2.9 \\
\hline Shrub removal & $7.2^{*}$ & 0.9 & 0.1 \\
\hline
\end{tabular}

\section{Discussion}

\section{Snow Depth Effects on Litter Decomposition}

Our study shows significant positive effects of experimental snow addition on shrub decomposition rates, partly supporting the snow-shrub hypothesis that the positive interaction between shrub growth and winter snow depth can drive tundra shrub expansion by enhancing winter plant decomposition rates and increasing litter $\mathrm{N}$-release and shrub N uptake (Sturm and others 2005b; Hallinger and others 2010). However, this hypothesis was based on correlations between snow depth and shrub height along natural gradients and was not experimentally validated as a positive feedback mechanism to explain the observed increase in shrub cover across the tundra biome (Tape and others 2006; Myers-Smith and others 2011). Our results provide a mechanistic explanation for the observed positive shrub growth response to deeper winter snow that has been observed earlier in a snow manipulation experiment in High-Arctic Svalbard (Blok and others 2015). Our results are in line with litter incubation studies performed along transects of natural snow depth gradients in alpine tundra grasslands (Baptist and others 2010; Saccone and others 2013; Carbognani and others 2014), which all show consistent positive effects of late versus early snowmelt on decomposition rates. Comparable experimental studies on the effects of elevated snow depth on plant litter decomposition rates performed in arctic tundra ecosystems are rare, but so far have not shown any significant effects of deepened snow on decomposition rates. Recently, DeMarco and others (2014) showed significant effects of shrub cover on decomposition rates of a common substrate in a 

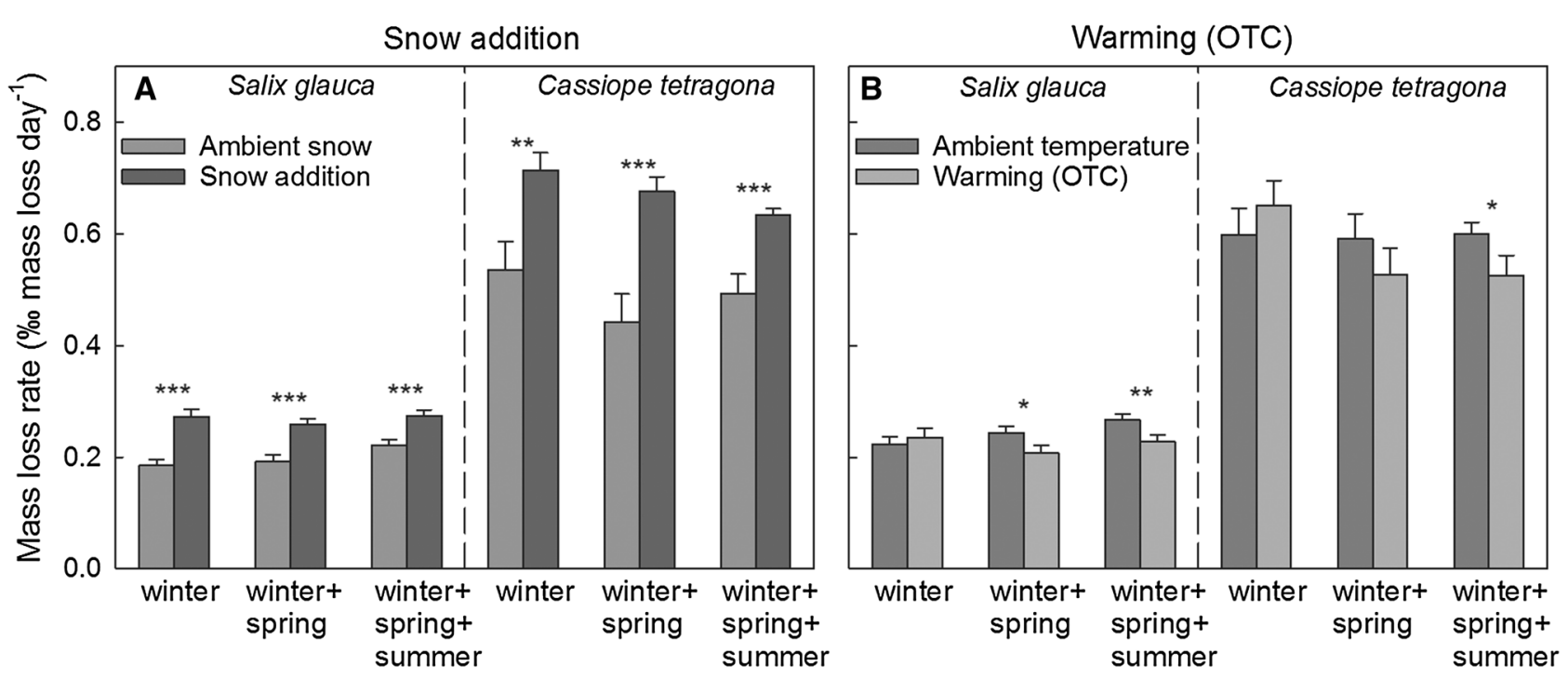

Figure 3. Average daily mass loss rates of Salix glauca leaf litter and Cassiope tetragona shoots in plots with snow addition (A) and warming (B) after incubation during winter, winter-spring, and winter-spring-summer. Values are means $(n=24$ litterbags treatment ${ }^{-1}$ incubation period $\left.{ }^{-1}\right)$. Symbols above bars indicate significance levels of treatment: ${ }^{*} P<0.05$, $* * P<0.01,{ }^{* * *} P<0.001$. Only snow addition and warming (OTC) showed significant treatment effects and are therefore presented.

tundra ecosystem, but not of experimentally increased snow depth. Aerts and others (2012) measured mass loss of graminoid (Calamagrostis lapponica), deciduous shrub (Betula nana) and perennial herb (Rubus chamaemorus) leaf litter after 2 and 4 years incubation in plots with elevated and ambient snow depths, but did not observe significant snow depth effects on mass loss for any litter type. Likewise, Walker and others (1999) did not show significant effects of snow depth on Betula nana mass loss in a tundra ecosystem even with a large snow depth increase $(2-3 \mathrm{~m})$. Although all three of these experimental studies do not reveal significant effects of winter snow depth on mass loss, they do indicate non-significant greater mass loss in snow addition plots compared to ambient snow plots. The high replication number in our three-way factorial experiment might have compensated for the random variation that is inherent in decomposition studies and thereby allowed detection of significant treatment effects. Although the absolute differences in first-year mass loss were small between snow-manipulated and ambient snow plots in our study, relative mass loss differences between treatments were substantial and comparable to differences in mass loss observed between markedly contrasting plant functional types such as graminoids and evergreen shrubs (Cornelissen and others 2007).

Our results do not support the hypothesis that increased litter decomposition rates, driven by deeper snow, initiate a positive feedback to taller shrub growth through higher winter litter N-mineralization (Sturm and others 2001). We cannot, however, exclude the possibility that deeper winter snow increases litter $\mathrm{N}$-mineralization during later stages of decomposition. Although in our experiment litter mass loss increased with deeper winter snow, we did not observe a significant effect of snow addition on litter $\mathrm{N}$ dynamics during the entire incubation period. This result is in line with results from a 3-year litter incubation experiment in Alaska that used snow fences to manipulate snow depth (DeMarco and others 2014) but is in contrast to another Alaskan litter decomposition study showing a significant net $\mathrm{N}$-release during the first winter of litter decomposition (Hobbie and Chapin 1996). In our study, $\mathrm{N}$-pools of $C$. tetragona shoots revealed a different temporal pattern than $\mathrm{N}$-pools of $S$. glauca leaves and showed initial $\mathrm{N}$ immobilization during winter, followed by net $\mathrm{N}$ release during spring and summer towards pre-incubation N-pool values. This pattern might be explained by a rapid microbial colonization of $C$. tetragona green shoots, with low C:N ratios, by fastgrowing microbial communities during the earliest stages of decomposition in the winter-time, followed by a rapid succession in spring and summer towards slower-growing microbial communities in sequential litter decay stages coinciding with lower C. tetragona shoot C:N ratios (Voriskova and Baldrian 2013). We observed loss of leaf and shoot 
${ }^{15} \mathrm{~N}$-pools, but stable or increasing total $\mathrm{N}$ pools during first-year decomposition, suggesting colonization of microbes might have compensated for leaching of sugars and amino acids from leaves and shoots.

A major part of the first-year mass loss occurred during winter, which is consistent with a seasonal litter decomposition study in an Alaskan tundra site by Hobbie and Chapin (1996). Leaching of soluble organic substances during the first stages of decomposition during winter might have been responsible for the observed high winter mass loss rates, and could decline during later decomposition stages of cellulose and lignin degradation (Berg and McClaugherty 2003). An experiment that mimicked extreme winter warming events and midwinter snowmelt, conducted in Northern Sweden, did not reveal significant effects on decomposition rates despite the large changes in temperature involved during the warming events (Bokhorst and others 2010). The authors concluded that little or no decomposition occurs during the winter season and all litter mass loss is by leaching during fall, although a more recent study suggests that the effects of snow depth on decomposition are species dependent (Bokhorst and others 2013b). In our study, we cannot exclude the possibility that leaching caused most of the observed winter mass loss. Soil moisture conditions during winter were the same between snow addition and ambient snow plots and thus were not likely causing the observed differences in mass loss, suggesting that higher winter temperatures in the litter layer drove higher rates of microbial decomposition of litter during the snow-covered winter incubation period. Previous experimental work demonstrated that microbial activity can continue during winter at temperatures well below zero, resulting in higher soil $\mathrm{N}$-mineralization rates with deeper snow (Schimel and others 2004). This result supports the hypothesis that microbial degradation might have contributed to the observed increase in winter mass loss in snow addition plots. Indeed, bacterial growth has been found to continue down to $-7^{\circ} \mathrm{C}$ in the relatively mild climate zone of sub-arctic Sweden (Rinnan and others 2009), well below daily average winter surface air temperatures measured in our snow addition plots. Fungal activity has been found to persist at even lower temperatures (Pietikåinen and others 2005), further supporting the hypothesis that plant litter decomposition might continue during winter-time under a deep-snow layer.

Snowmelt occurred unusually early at our research site during 2013, the year when litterbags were harvested. This early melt resulted in pronounced differences in snow melt timing between ambient and snow addition plots of up to two months. Nevertheless, extreme differences in snowmelt timing also occurred naturally at our site, depending on local topography, shrub height, and exposure. The vegetation in our experiment will not likely grow to a height to achieve the degree of snow accumulation through shrub snow-capture as achieved by our snow fences. However, tall shrubs (up to $1.5 \mathrm{~m}$ tall) do occur in our research area and accumulate similar depths of snow, but are restricted to patches in the landscape with high relief. We observed that these tall shrub patches with thick snow cover melted out around the same time as our snow-manipulated plots.

\section{Spring and Summer Warming Effects on Litter Decomposition}

In contrast to our second hypothesis, the warming treatment (OTC) reduced decomposition during spring (but not during summer), which we consider might be due to the indirect negative effect of warming on litter moisture content, leading to microbial water limitation in the top surface litter layer. We hypothesize that the litter layer might have dried out more quickly in the OTCs than in the ambient temperature control plots (Robinson and others 1997; Schimel and others 1999; Sjögersten and Wookey 2004; Bokhorst and others 2013a). Hicks Pries and others (2013) recently showed moisture limitation was the most significant driver of decomposition rates in arctic tundra. Together with our results, this result suggests that predicted warmer and drier arctic growing conditions in the coming decades might decrease litter decomposition rates in tundra ecosystems during the snow-free growing season, possibly reducing $\mathrm{C}$ and $\mathrm{N}$ cycling rates and thus providing a negative feedback to shrub expansion by decreasing $\mathrm{N}$ availability to shrubs. This hypothesis might partly explain the spatial heterogeneity in the growth response of shrubs to temperature in arctic tundra, observed to be strongest in moist tundra but declining towards drier tundra, which might be linked to differences in N-limitation for shrub growth across tundra moisture gradients (MyersSmith and others 2015). We did not observe a significant effect of warming (OTC) on mass loss during the summer period, possibly because this period had more precipitation events and pulses of moisture supply to the litter layer than during the dry spring period (Fig. 1C). 


\section{Shrub Removal Effects on Litter Decomposition}

We did not find evidence supporting our third hypothesis, as we observed no consistent effect of shrub removal on decomposition rates, with only $C$. tetragona shoot decomposition showing a small significant positive response during the summer incubation period. This result is in agreement with a study on shrub canopy height effects on decomposition rates performed in a Canadian arctic tundra site that found no differences in litter decomposition rates in plots with or without a shrub canopy (Myers-Smith and Hik 2013). At our site, the effect of shrub removal might have been limited because of the low-statured vegetation, whereas greater effects of shrub removal on albedodriven changes in surface temperature could be expected in tall shrub tundra (Bonfils and others 2012). Similarly, the effect of shrub shading on decomposition of leaves and shoots incubated at the top of the soil/lichen surface might have been limited because of the short stature of shrubs at our site.

\section{Winter versus Summer Warming Effects on Litter Decomposition}

Our results provided support for our fourth hypothesis, as we observed greater (positive) effects of our snow addition treatment compared to the (negative) effects of our summer warming treatment on litter mass loss, despite the average higher surface air temperature increase achieved by the OTCs during spring and summer compared to the winter surface soil warming achieved by the snow addition treatment. Instead, this difference in treatment effect among the winter and spring/summer incubation periods might be attributed to the relative longer period of time that plots were exposed to the snow addition compared to the warming (OTC) treatment. Our results suggest that under a climate change scenario whereby both winter snow precipitation and summer temperature would increase, the earlier effect on litter decomposition rates might dominate. However, the litter decomposition response to winter snow addition is likely related to the amount of snow addition, as well as dependent on drought conditions during the snow-free season. Moisture conditions of the surface litter layer, where we incubated the litters, are highly responsive to spring and summer weather conditions. As such, the OTCs might have had a positive effect on litter mass loss if growing season conditions were cool and wet instead of the dry and warm growing season conditions during the course of our experiment, assuming that the negative effect of the OTCs on litter mass loss was related to microbial water limitation. We did not observe any interaction effect among the winter snow addition and spring/summer warming treatments, suggesting that the earlier treatment did not have carry-over effects that influenced the effects of warming on litter decomposition during the growing season.

\section{Species-Specific Litter Decomposition Responses}

Our fifth hypothesis, stating that the decomposition response to treatments is greater for low-quality tissue, was confirmed by greater effects of both snow addition and warming on litter mass loss of $S$. glauca leaves compared to green $C$. tetragona shoots. This result suggests that decomposition of recalcitrant plant matter might be more affected by climatic changes than fast-decomposing material. However, the short incubation period in our study allows only an assessment of climate change impacts on early decomposition stages. Longer term climate effects on litter decomposition rates might differ from short-term effects through their impact on N-release and plant-soil feedbacks because net litter $\mathrm{N}$-mineralization has been found to require several years in cold tundra ecosystems (Aerts and others 2012).

\section{ConClusions}

Our results show that while deeper snow speeds up shrub decomposition during initial decomposition stages during winter, deeper snow does not promote net litter N-release. However, this result does not preclude the possibility that positive feedbacks between snow, litter decomposition rates, and shrub growth might occur during later stages of decomposition stages when litter $\mathrm{N}$-mineralization does occur. In contrast to the observed positive effects of deeper snow, spring warming reduced decomposition rates, possibly because of microbial moisture limitation. In summary, our study shows contrasting impacts of deeper winter snow and spring warming on shrub decomposition rates, highlighting the importance of taking into account both winter and growing season climate change impacts on shrub decomposition rates in tundra ecosystems. These climate-driven changes in decomposition rates might have important consequences for plant community composition and vegetation-climate feedbacks in rapidly changing tundra ecosystems. Future research is needed to 
integrate summer and winter climate change effects on tundra litter decomposition rates. Novel experimental studies are required to assess if climate change-driven changes in litter decomposition rates may be linked to changes in shrub nitrogen acquisition, thus providing a mechanistic explanation for the widespread expansion of shrubs observed in tundra ecosystems during the last decades.

\section{ACKNOWLEDGEMENTS}

We thank Ole Stecher, Akaaraq Mølgaard, Paul Christiansen, and Per Freiberg for logistic support. We thank Naalu Mølgaard for leaf and shoot collection. We thank Nynne Larsen, Ludovica D'Imperio, and Morten Rolsted for collection of litterbags. We thank Sue Natali and Elisabeth Cooper for advice on snowfence construction. We thank Andreas Westergaard-Nielsen and Jens Gammeltoft for setting up automated cameras. We thank Kent Pørksen for providing photos of the experimental site. We thank Annelein Meisner for assisting with the establishment of the experiment and commenting on a previous version of the manuscript. We thank Helle Sørensen for advice on statistical mixed-model analysis. We kindly thank the reviewers and subject-editor Edward Rastetter for their helpful comments which greatly improved the paper. This work was funded by a grant from the Danish National Research Foundation (CENPERM DNRF100).

\section{DATA ACCESSIBILITY}

Data used in this study will be deposited in the Dryad ecological data archive after acceptance of the manuscript (www.datadryad.org).

\section{OPEN ACCESS}

This article is distributed under the terms of the Creative Commons Attribution 4.0 International License (http://creativecommons.org/licenses/by/4.0/), which permits unrestricted use, distribution, and reproduction in any medium, provided you give appropriate credit to the original author(s) and the source, provide a link to the Creative Commons license, and indicate if changes were made.

\section{REFERENCES}

Aerts R. 2006. The freezer defrosting: global warming and litter decomposition rates in cold biomes. J Ecol 94:713-24.

Aerts R, Callaghan TV, Dorrepaal E, Logtestijn RSP, Cornelissen JHC. 2012. Seasonal climate manipulations have only minor effects on litter decomposition rates and $\mathrm{N}$ dynamics but strong effects on litter P dynamics of sub-arctic bog species. Oecologia 170:809-19.

Baptist F, Yoccoz NG, Choler P. 2010. Direct and indirect control by snow cover over decomposition in alpine tundra along a snowmelt gradient. Plant Soil 328:397-410.

Berg B, McClaugherty C. 2003. Plant Litter-decomposition, humus formation, carbon sequestration. Berlin: Springer.

Bintanja R, Selten FM. 2014. Future increases in arctic precipitation linked to local evaporation and sea-ice retreat. Nature 509:479-82.

Blok D, Heijmans MMPD, Schaepman-Strub G, Kononov AV, Maximov TC, Berendse F. 2010. Shrub expansion may reduce summer permafrost thaw in Siberian tundra. Glob Change Biol 16:1296-305.

Blok D, Weijers S, Welker JM, Cooper EJ, Michelsen A, Löffler J, Elberling B. 2015. Deepened winter snow increases stem growth and alters stem $\delta^{13} \mathrm{C}$ and $\delta^{15} \mathrm{~N}$ in evergreen dwarf shrub Cassiope tetragona in high-arctic Svalbard tundra. Environmental Research Letters 10:044008.

Bokhorst S, Bjerke JW, Melillo J, Callaghan TV, Phoenix GK. 2010. Impacts of extreme winter warming events on litter decomposition in a sub-Arctic heathland. Soil Biol Biochem 42:611-17.

Bokhorst S, Huiskes A, Aerts R, Convey P, Cooper EJ, Dalen L, Erschbamer B, Gudmundsson J, Hofgaard A, Hollister RD, Johnstone J, Jónsdóttir IS, Lebouvier M, Van de Vijver B, Wahren C-H, Dorrepaal E. 2013a. Variable temperature effects of Open Top Chambers at polar and alpine sites explained by irradiance and snow depth. Glob Change Biol 19:64-74.

Bokhorst S, Metcalfe DB, Wardle DA. 2013b. Reduction in snow depth negatively affects decomposers but impact on decomposition rates is substrate dependent. Soil Biol Biochem 62:157-64.

Bokhorst S, Wardle DA. 2013. Microclimate within litter bags of different mesh size: implications for the 'arthropod effect' on litter decomposition. Soil Biol Biochem 58:147-52.

Bonan GB, Hartman MD, Parton WJ, Wieder WR. 2013. Evaluating litter decomposition in earth system models with long-term litterbag experiments: an example using the Community Land Model version 4 (CLM4). Glob Change Biol 19:957-74.

Bonfils CJW, Phillips TJ, Lawrence DM, Cameron-Smith P, Riley WJ, Subin ZM. 2012. On the influence of shrub height and expansion on northern high latitude climate. Environmental Research Letters 7:015503.

Buckeridge K, Zufelt E, Chu H, Grogan P. 2010. Soil nitrogen cycling rates in low arctic shrub tundra are enhanced by litter feedbacks. Plant Soil 330:407-21.

Carbognani M, Petraglia A, Tomaselli M. 2014. Warming effects and plant trait control on the early-decomposition in alpine snowbeds. Plant Soil 376:277-90.

Chapin FSIII, Sturm M, Serreze MC, McFadden JP, Key JR, Lloyd AH, McGuire AD, Rupp TS, Lynch AH, Schimel JP, Beringer J, Chapman WL, Epstein HE, Euskirchen ES, Hinzman LD, Jia G, Ping CL, Tape KD, Thompson CDC, Walker DA, Welker JM. 2005. Role of land-surface changes in arctic summer warming. Science 310:657-60.

Cornelissen JHC, Makoto K. 2013. Winter climate change, plant traits and nutrient and carbon cycling in cold biomes. Ecol Res 29:517-27.

Cornelissen JHC, van Bodegom PM, Aerts R, Callaghan TV, van Logtestijn RSP, Alatalo J, Chapin FSIII, Gerdol R, Gud- 
mundsson J, Gwynn-Jones D, Hartley AE, Hik DS, Hofgaard A, Jonsdottir IS, Karlsson S, Klein JA, Laundre J, Magnusson B, Michelsen A, Molau U, Onipchenko VG, Quested HM, Sandvik SM, Schmidt IK, Shaver GR, Solheim B, Soudzilovskaia NA, Stenstrom A, Tolvanen A, Totland O, Wada N, Welker JM, Zhao XQ, Team MOL. 2007. Global negative vegetation feedback to climate warming responses of leaf litter decomposition rates in cold biomes. Ecol Lett 10:619-27.

DeMarco J, Mack MC, Bret-Harte MS. 2011. The effects of snow, soil microenvironment, and soil organic matter quality on $\mathrm{N}$ availability in three alaskan arctic plant communities. Ecosystems 14:804-17.

DeMarco J, Mack MC, Bret-Harte MS. 2014. Effects of arctic shrub expansion on biophysical vs. biogeochemical drivers of litter decomposition. Ecology 95:1861-75.

Elmendorf SC, Henry GHR, Hollister RD, Björk RG, Bjorkman AD, Callaghan TV, Collier LS, Cooper EJ, Cornelissen JHC, Day TA, Fosaa AM, Gould WA, Grétarsdóttir J, Harte J, Hermanutz L, Hik DS, Hofgaard A, Jarrad F, Jónsdóttir IS, Keuper F, Klanderud K, Klein JA, Koh S, Kudo G, Lang SI, Loewen V, May JL, Mercado J, Michelsen A, Molau U, Myers-Smith IH, Oberbauer SF, Pieper S, Post E, Rixen C, Robinson CH, Schmidt NM, Shaver GR, Stenström A, Tolvanen A, Totland Ø, Troxler T, Wahren C-H, Webber PJ, Welker JM, Wookey PA. 2012a. Global assessment of experimental climate warming on tundra vegetation: heterogeneity over space and time. Ecol Lett 15:164-75.

Elmendorf SC, Henry GHR, Hollister RD, Bjork RG, BoulangerLapointe N, Cooper EJ, Cornelissen JHC, Day TA, Dorrepaal E, Elumeeva TG, Gill M, Gould WA, Harte J, Hik DS, Hofgaard A, Johnson DR, Johnstone JF, Jonsdottir IS, Jorgenson JC, Klanderud K, Klein JA, Koh S, Kudo G, Lara M, Levesque E, Magnusson B, May JL, Mercado-Diaz JA, Michelsen A, Molau U, Myers-Smith IH, Oberbauer SF, Onipchenko VG, Rixen C, Martin Schmidt N, Shaver GR, Spasojevic MJ, Orhallsdottir OE, Tolvanen A, Troxler T, Tweedie CE, Villareal S, Wahren C-H, Walker X, Webber PJ, Welker JM, Wipf S. 2012b. Plotscale evidence of tundra vegetation change and links to recent summer warming. Nat Clim Change 2:453-7.

Fierer N, Craine JM, McLauchlan K, Schimel JP. 2005. Litter quality and the temperature sensitivity of decomposition. Ecology 86:320-6.

Freschet GT, Aerts R, Cornelissen JHC. 2012. A plant economics spectrum of litter decomposability. Funct Ecol 26:56-65.

Hallinger M, Manthey M, Wilmking M. 2010. Establishing a missing link: warm summers and winter snow cover promote shrub expansion into alpine tundra in Scandinavia. New Phytol 186:890-9.

Hansen BU, Elberling B, Humlum O, Nielsen N. 2006. Meteorological trends (1991-2004) at Arctic Station, Central West Greenland $\left(69^{\circ} 15^{\prime} \mathrm{N}\right)$ in a 130 years perspective. Danish J Geogr 106:45-55.

Hicks Pries CE, Schuur EAG, Vogel JG, Natali SM. 2013. Moisture drives surface decomposition in thawing tundra. J Geophys Res 118:1133-43.

Hobbie SE. 1996. Temperature and plant species control over litter decomposition in Alaskan tundra. Ecol Monogr 66:50322.

Hobbie SE, Chapin FSIII. 1996. Winter regulation of tundra litter carbon and nitrogen dynamics. Biogeochemistry 35:327-38.

IPCC. 2013. Climate Change 2013: The Physical Science Basis. In: Stocker TF, Qin D, Plattner G-K, Tignor M, Allen SK, Boschung J, Nauels A, Xia Y, Bex V, Midgley PM, Eds. Con- tribution of Working Group I to the Fifth Assessment Report of the Intergovernmental Panel on Climate Change. Cambridge, UK: New York. p 1535.

Lupascu M, Welker JM, Seibt U, Maseyk K, Xu X, Czimczik CI. 2014. High Arctic wetting reduces permafrost carbon feedbacks to climate warming. Nature Clim. Change 4:51-5.

Mack MC, Schuur EAG, Bret-Harte MS, Shaver GR, Chapin FSIII. 2004. Ecosystem carbon storage in arctic tundra reduced by long-term nutrient fertilization. Nature 431:440-3.

Myers-Smith IH, Elmendorf SC, Beck PSA, Wilmking M, Hallinger M, Blok D, Tape KD, Rayback SA, Macias-Fauria M, Forbes BC, Speed JDM, Boulanger-Lapointe N, Rixen C, Levesque E, Schmidt NM, Baittinger C, Trant AJ, Hermanutz L, Collier LS, Dawes MA, Lantz TC, Weijers S, Jorgensen RH, Buchwal A, Buras A, Naito AT, Ravolainen V, SchaepmanStrub G, Wheeler JA, Wipf S, Guay KC, Hik DS, Vellend M. 2015. Climate sensitivity of shrub growth across the tundra biome. Nature Clim Change 5:887-91.

Myers-Smith IH, Forbes BC, Wilmking M, Hallinger M, Lantz T, Blok D, Tape KD, Macias-Fauria M, Sass-Klaassen U, Lévesque E, Boudreau S, Ropars P, Hermanutz L, Trant A, Collier LS, Weijers S, Rozema J, Rayback SA, Schmidt NM, SchaepmanStrub G, Wipf S, Rixen C, Ménard CB, Venn S, Goetz S, Andreu-Hayles L, Elmendorf S, Ravolainen V, Welker J, Grogan P, Epstein HE, Hik DS. 2011. Shrub expansion in tundra ecosystems: dynamics, impacts and research priorities. Environ Res Lett 6:045509.

Myers-Smith IH, Hik DS. 2013. Shrub canopies influence soil temperatures but not nutrient dynamics: an experimental test of tundra snow-shrub interactions. Ecol Evol 3:3683-700.

Natali SM, Schuur EAG, Rubin RL. 2012. Increased plant productivity in Alaskan tundra as a result of experimental warming of soil and permafrost. J Ecol 100:488-98.

Natali SM, Schuur EAG, Webb EE, Pries CEH, Crummer KG. 2014. Permafrost degradation stimulates carbon loss from experimentally warmed tundra. Ecology 95:602-8.

Pietikåinen J, Pettersson M, Båăth E. 2005. Comparison of temperature effects on soil respiration and bacterial and fungal growth rates. FEMS Microbiol Ecol 52:49-58.

Rinnan R, Rousk J, Yergeau E, Kowalchuk GA, Bååth E. 2009. Temperature adaptation of soil bacterial communities along an Antarctic climate gradient: predicting responses to climate warming. Glob Change Biol 15:2615-25.

Robinson CH, Michelsen A, Lee JA, Whitehead SJ, Callaghan TV, Press MC, Jonasson S. 1997. Elevated atmospheric $\mathrm{CO}_{2}$ affects decomposition of Festuca vivipara (L.) Sm. litter and roots in experiments simulating environmental change in two contrasting arctic ecosystems. Glob Change Biol 3:37-49.

Robinson CH, Wookey PA, Parsons AN, Potter JA, Callaghan TV, Lee JA, Press MC, Welker JM. 1995. Responses of plant litter decomposition and nitrogen mineralisation to simulated environmental change in a high arctic polar semi-desert and a subarctic dwarf shrub heath. Oikos 74:503-12.

Saccone P, Morin S, Baptist F, Bonneville J-M, Colace M-P, Domine F, Faure M, Geremia R, Lochet J, Poly F, Lavorel S, Clément J-C. 2013. The effects of snowpack properties and plant strategies on litter decomposition during winter in subalpine meadows. Plant Soil 363:215-29.

Schimel JP, Bilbrough C, Welker JM. 2004. Increased snow depth affects microbial activity and nitrogen mineralization in two arctic tundra communities. Soil Biol Biochem 36:217.

Schimel JP, Gulledge JM, Clein-Curley JS, Lindstrom JE, Braddock JF. 1999. Moisture effects on microbial activity and 
community structure in decomposing birch litter in the Alaskan taiga. Soil Biol Biochem 31:831-8.

Semenchuk PR, Elberling B, Amtorp C, Winkler J, Rumpf S, Michelsen A, Cooper EJ. 2015. Deeper snow alters soil nutrient availability and leaf nutrient status in high Arctic tundra. Biogeochemistry 124:81-94.

Sistla SA, Rastetter EB, Schimel JP. 2014. Responses of a tundra system to warming using SCAMPS: a stoichiometrically coupled, acclimating microbe-plant-soil model. Ecol Monogr 84:151-70.

Sjögersten S, Wookey PA. 2004. Decomposition of mountain birch leaf litter at the forest-tundra ecotone in the Fennoscandian mountains in relation to climate and soil conditions. Plant Soil 262:215-27.

Sturm M, Douglas T, Racine C, Liston GE. 2005a. Changing snow and shrub conditions affect albedo with global implications. J Geophys Res 110:10-13.

Sturm M, McFadden JP, Liston GE, Chapin FSIII, Racine $\mathrm{CH}$, Holmgren J. 2001. Snow-shrub interactions in arctic tundra: a hypothesis with climatic implications. J Clim 14:33644.

Sturm M, Schimel JP, Michaelson GJ, Welker JM, Oberbauer SF, Liston GE, Fahnestock JT, Romanovsky VE. 2005b. Winter biological processes could help convert arctic tundra to shrubland. Bioscience 55:17-26.

Sundqvist MK, Giesler R, Wardle DA. 2011. Within- and acrossspecies responses of plant traits and litter decomposition to elevation across contrasting vegetation types in subarctic tundra. PLoS One 6:e27056.
Tape K, Sturm M, Racine C. 2006. The evidence for shrub expansion in Northern Alaska and the Pan-Arctic. Glob Change Biol 12:686-702.

Vankoughnett MR, Grogan P. 2014. Nitrogen isotope tracer acquisition in low and tall birch tundra plant communities: a 2 year test of the snow-shrub hypothesis. Biogeochemistry 118:291-306.

Voriskova J, Baldrian P. 2013. Fungal community on decomposing leaf litter undergoes rapid successional changes. ISME J 7:477-86.

Walker MD, Walker DA, Welker JM, Arft AM, Bardsley T, Brooks PD, Fahnestock JT, Jones MH, Losleben M, Parsons AN, Seastedt TR, Turner PL. 1999. Long-term experimental manipulation of winter snow regime and summer temperature in arctic and alpine tundra. Hydrol Process 13:2315-30.

Wieder WR, Bonan GB, Allison SD. 2013. Global soil carbon projections are improved by modelling microbial processes. Nat Clim Change 3:909-12.

Wookey PA, Aerts R, Bardgett RD, Baptist F, Bråthen KA, Cornelissen JHC, Gough L, Hartley IP, Hopkins DW, Lavorel S, Shaver GR. 2009. Ecosystem feedbacks and cascade processes: understanding their role in the responses of Arctic and alpine ecosystems to environmental change. Glob Change Biol 15:1153-72.

Zeller B, Colin-Belgrand M, Dambrine E, Martin F. $1998 .{ }^{15} \mathrm{~N}$ partitioning and production of ${ }^{15} \mathrm{~N}$-labelled litter in beech trees following $\left[{ }^{15} \mathrm{~N}\right]$ urea spray. Ann Sci For 55:375-83. 